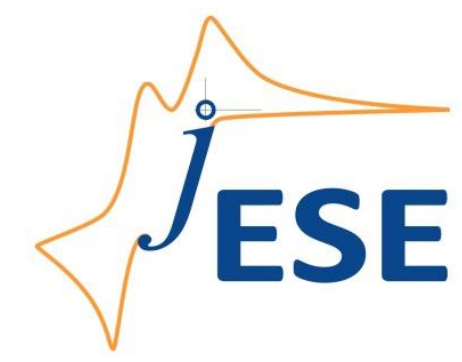

Open Access : : ISSN 1847-9286

www.jESE-online.org

Original scientific paper

\title{
Preparation and properties of electrodeposited $\mathrm{Ni}_{-} \mathrm{TiO}_{2}$ composite coating
}

\author{
Sukhdev Singh Bhogal ${ }^{凶}$, Vijay Kumar*, Sukhdeep Singh Dhami and Bahadur Singh \\ Pabla \\ National Institute of Technical Teachers and Research, Sector-26, Chandigarh, India \\ *Punjab Technical University Campus, SAS Nagar (Mohali)-Punjab, India \\ Corresponding Author: sukhdev bhogal@yahoo.com
}

Received: 4 November 2014; Revised: 7 January 2015; Published: March 15, 2015

\begin{abstract}
The mechanical properties of cutting tools, such as microhardness, corrosion resistance, and coating adhesiveness, directly affect the tool life and indirectly affect the component cost. In this paper, $\mathrm{Ni}_{-} \mathrm{TiO}_{2}$ composite coating was prepared through electrocodeposition in order to improve the mechanical properties of tungsten carbide cutting tools. The microhardness of the $\mathrm{Ni}^{-} \mathrm{TiO}_{2}$ composite layer was studied by varying the input current density $\left(\mathrm{mA} \mathrm{cm}^{-2}\right), \mathrm{pH}$ value of the electrolyte, and particle concentration of $\mathrm{TiO}_{2}$ in electrolyte bath. The microstructure and phase structure of the composite layer were investigated using atomic force microscopy, scanning electronic microscopy and X-ray diffraction. The surface morphology of the $\mathrm{Ni}^{-T i O}{ }_{2}$ coated layer shows fine-grained structures and higher microhardness at lower currents. The maximum microhardness of the coated layer, $1483 \mathrm{HV}$, is found at a current of $15 \mathrm{~mA} \mathrm{~cm}{ }^{-2}$ and Watts solution $\mathrm{pH}$ of 4.5. It is observed that with the increase of $\mathrm{TiO}_{2}$ content, the microhardness of the coating also increases.
\end{abstract}

\section{Keywords}

Microhardness; Electrocodeposition; Ccomposite layers

\section{Introduction}

$\mathrm{TiO}_{2}$ is well known as a metal dioxide ceramic which has been utilized in many applications for its fine physical and chemical properties. Nano-size $\mathrm{TiO}_{2}$ particles are usually introduced into nickelbased composite coating to enhance its properties such as corrosion resistance, microhardness, and abrasiveness [1]. Electrodeposition is one of the traditional processes used for the 
improvement of the surface. Specially, it is used for the enhancement of coating properties such decorativeness, functionality, and electroforming of the coated surfaces. This method has advantages like low cost, low temperature, ease of use, and being a single-step process that does not require additional thermal treatment [2]. In the manufacturing industry, metal cutting tools are in high demand due to their greater sustainably in the cutting of hard materials, as tough conditions of high cutting force and high contact pressure between the workpiece and tool materials are found during machining. Further cutting conditions and tool shape, make the tool condition to the severity and ultimately causes the earlier tool failure. Mostly the cutting tools which are used have more ultimate resistance against the load and ability to limit the thermal and mechanical stresses during cutting of hard and difficult-to-cut materials. Nowadays, highperformance cutting tool materials obtained with chemical vapour deposition (CVD) and physical vapour deposition (PVD) as well as other coated carbides like cermets, ceramics, cubic boron nitride, and diamond-coated tools are frequently used, but tungsten carbide (WC)-coated tools are also in use for metal-cutting applications due to their high strength and the fact that they can be manufactured economically with complicated geometries.

Protective coatings on cutting tools have been in use for a little more than three decades. The search for wear-resistant materials has since been redirected to encompass material properties other than just hardness. Cutting performance is also dependent on both the cutting tool and the machine tool system, that is, on the tool material, cutting tool geometry, and hard coating [3]. In the early twenty century hard coatings were deposited by CVD and PVD by a magnetron sputtering process. Magnetron sputtering is preferred to the CVD process due to the contamination that occurs in the latter [4]. Single-layer coatings such as $\mathrm{TiN}, \mathrm{TiC}, \mathrm{CrN}, \mathrm{DLC}, \mathrm{Ti}_{-} \mathrm{O}_{2}$, and AIN played an important role a few years ago, due to their mechanical and tribological properties [5]. Nowadays, these coatings are being mixed, designed, and improved by creating hetero-structured thin films and multilayered coatings with periods in the range of nanometres, which is one of the advanced coating concepts more commonly investigated during the last two decades, together with nanocomposites [6,7]. The nanocomposite coatings range from 3 to $10 \mathrm{~nm}$ in size, have been selected from nitrides, carbides, borides, and oxides, and are embedded in an amorphous or crystalline matrix. The large volume of grain boundaries provides ductility through sliding of the grain boundary along grain/matrix interfaces. These coatings have sometimes been reported to have hardnesses of up to $100 \mathrm{GPa}[8,9]$.

Electrodeposition offers some unique advantages over other techniques such as improved appearance, corrosion resistance, and physiochemical properties of surfaces which find potential applications in the fabrication of advanced components for micro-/nano-electromechanical systems (MEMS/NEMS). Moreover the initial setup cost for coating by electrodeposition is quite low compared to other conventional coating processes like CVD and PVD. Moreover fine structure growth and easy control of the coating thickness up to fractions of a micrometre are possible via electrodeposition. The aim of this work is to evaluate the influence of $\mathrm{Ni}-\mathrm{TiO}_{2}$ composite coatings deposited onto a WC cutting tool by the electrodeposition technique. $\mathrm{Ni}-\mathrm{TiO}_{2}$ composite coating was employed to investigate the microhardness behaviour, adhesion to the substrate, and coating thickness with different currents at constant temperature and deposition time.

\section{Experimental details}

$\mathrm{Ni}-\mathrm{TiO}_{2}$ composites were electrodeposited from an organic free Watts nickel electrolyte with suspended $\mathrm{TiO}_{2}$ nanoparticles on the WC tool bits by electrodeposition. Electrodeposited nickel 
and composite $\mathrm{Ni}-\mathrm{TiO}_{2}$ coatings were prepared from Watts solution. The composition of the plating solution, as well as the plating conditions, is given in Table 1. All the chemicals used were of analytical grade with high purity and were purchased from Merck. A Gamry Reference 3000 potentiostat was used for coating. The triangular-shaped CNC tool bit (WC) was mechanically polished with different grades of emery papers (between 800 and 4000) and finally ultrasonically cleaned in acetone before electroplating without any activation pretreatment. The substrates were rinsed with doubly distilled water and dried under air.

A specially designed three-electrode electrodeposition cell was used for electrodeposition of $\mathrm{Ni}-\mathrm{TiO}_{2}$, where the cutting tool was the working electrode, $\mathrm{Ag} / \mathrm{AgCl}$ was the reference electrode, and $\mathrm{Pt}$ wire acted as the counter electrode (anode). The distance between the $\mathrm{Ag} / \mathrm{AgCl}$ reference electrode and the working electrode was $1 \mathrm{~cm}$. The particle size of $\mathrm{TiO}_{2}$ particles was about $50 \mathrm{~nm}$. It was used without any pretreatment and was kept in a bath in suspension by continuous magnetic stirring at a rate of $210 \mathrm{rpm}$ in order to maintain a uniform concentration of particles in the bulk solution. Before starting the electroplating, the electrolyte was placed in an ultrasonic bath for 20 min to prevent agglomeration of $\mathrm{TiO}_{2}$ particles.

Table 1. Watts solution for $\mathrm{Ni} / \mathrm{TiO}_{2}$ composite electrodeposits

\begin{tabular}{|l|c|}
\hline \multicolumn{2}{|c|}{ Electrolyte (Watts) solution composition } \\
\hline Concentration of $\mathrm{NiSO}_{4} 6 \mathrm{H}_{2} \mathrm{O}, \mathrm{g} \mathrm{L}^{-1}$ & 300 \\
Concentration of $\mathrm{NiCl}_{2} 6 \mathrm{H}_{2} \mathrm{O}, \mathrm{g} \mathrm{L}^{-1}$ & 45 \\
Concentration of $\mathrm{H}_{3} \mathrm{BO}_{3}, \mathrm{~g} \mathrm{~L}^{-1}$ & 40 \\
Concentration of $\mathrm{TiO}_{2}, \mathrm{~g} \mathrm{~L}^{-1}$ & 6 \\
$\mathrm{pH}$ of electrolyte & $4.4 \pm 0.1$ \\
Temperature, ${ }^{\circ} \mathrm{C}$ & 30 \\
Substrate & Tungsten carbide bit \\
Average current density, $\mathrm{mA} \mathrm{cm}^{-2}$ & $15,30,45$ \\
Agitation & $180 \mathrm{rpm}$ \\
Type of current & $\mathrm{DC}$ \\
\hline
\end{tabular}

The surface morphology of the $\mathrm{Ni}^{-\mathrm{TiO}_{2}}$ composite coating was determined by SEM (JEOL, JSM-6460LV) with energy dispersive X-ray analysis (EDS) and AFM. To determine the phase structure of $\mathrm{Ni}-\mathrm{TiO}_{2}$ composite coatings, X-ray diffraction (XRD) analysis was performed on a PW 1710 diffractometer with $\mathrm{Cu}-\mathrm{K} \alpha(\lambda=1.54 \mathrm{~A} 0)$ radiation. The operating target voltage was $40 \mathrm{kV}$ and the tube current was $100 \mathrm{~mA}$. Using the Scherrer equation, the average grain diameter could be calculated as follows:

$$
D=\frac{\kappa \lambda}{\omega \cos \theta}
$$

where $K$ is the constant of the grains $(K=0.89), \lambda$ the wavelength, $\omega$ the standard full width at half maximum (FWHM), and $\theta$ the Bragg angle. Vickers hardness was measured by applying a $0.5-\mathrm{kg}$ force load for 10 seconds using a Vickers hardness tester (Mitutoyo).

\section{Results and discussion}

The surface morphology and microstructure of the composite coating were investigated through Atomic Force Microscopy (AFM) and Scanning Electron Microscopy (SEM). The surface morphology and microstructure of the coating layer are discussed below. 


\section{Surface morphology and microstructure}

The composite coating was investigated by AFM. Figure 1 shows the AFM images of $\mathrm{Ni}^{-\mathrm{TiO}_{2}}$ composite coating surfaces $(20 \times 20 \mu \mathrm{m}$ area) on a tungsten carbide tool tip. Figures $1 \mathrm{a}$ and $1 \mathrm{~b}$ show the surface after deposition of the $\mathrm{Ni}-\mathrm{TiO}_{2}$ coating with $5 \mathrm{~mA}$ of current and a pH of the solution of 4.5 respectively. In order to compare the surface roughness ( $R a$ ) of the coatings, AFM data are used, and based on the experimental results, the $\mathrm{Ni}-\mathrm{TiO}_{2}$ composite coating prepared at lower current i.e. at $15 \mathrm{~mA}$ with $\mathrm{pH} 3.5$ of solution (Fig. 1a) shows a uniform and fine structure among the micro-regions, whereas the coating prepared with a lower current and $\mathrm{pH} 4.5$ of the Watts solution (Fig. 1b) appears to be finer and shows a regular crystalline grain structure. As the $\mathrm{pH}$ of the bath influences the hydrogen evolution voltage the precipitation of basic inclusion of solution and decomposition of the hydrated ion is deposited more freely. Thereby a finer and more uniform grain structure is obtained.

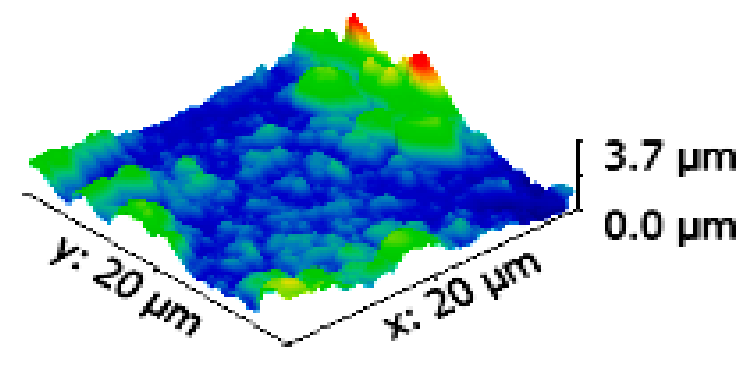

(a)

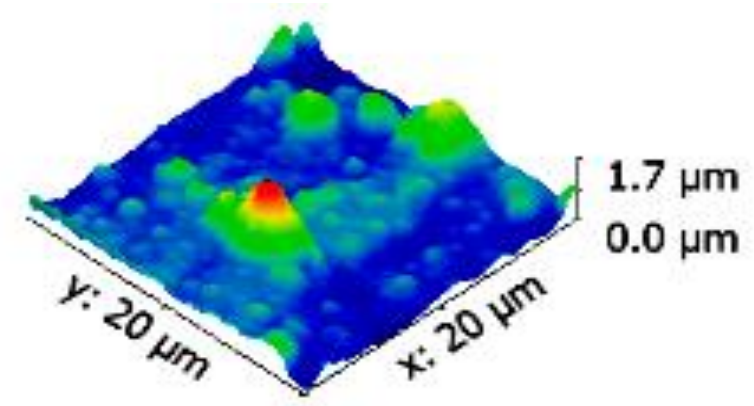

(b)

Figure 1. AFM images of $\mathrm{Ni}_{-} \mathrm{TiO}_{2}$ composite coating: (a) current $=15 \mathrm{~mA}$, temperature $=30^{\circ} \mathrm{C}$, and $\mathrm{pH}$ 3.5; (b) current $=15 \mathrm{~mA}$, temperature $=30^{\circ} \mathrm{C}$, and $\mathrm{pH} 4.5$

The XRD patterns of the $\mathrm{Ni}^{-\mathrm{TiO}_{2}}$ (Fig. 2) composite coatings were detected by XRD to further confirm the existence of $\mathrm{TiO}_{2}$ particles. Scans were recorded for the range $2 \theta=20-80^{\circ}$ with a scan step of $0.02^{\circ}$. The XRD patterns of the three types of $\mathrm{Ni}-\mathrm{TiO}_{2}$ composite coatings are presented in Fig. 2.

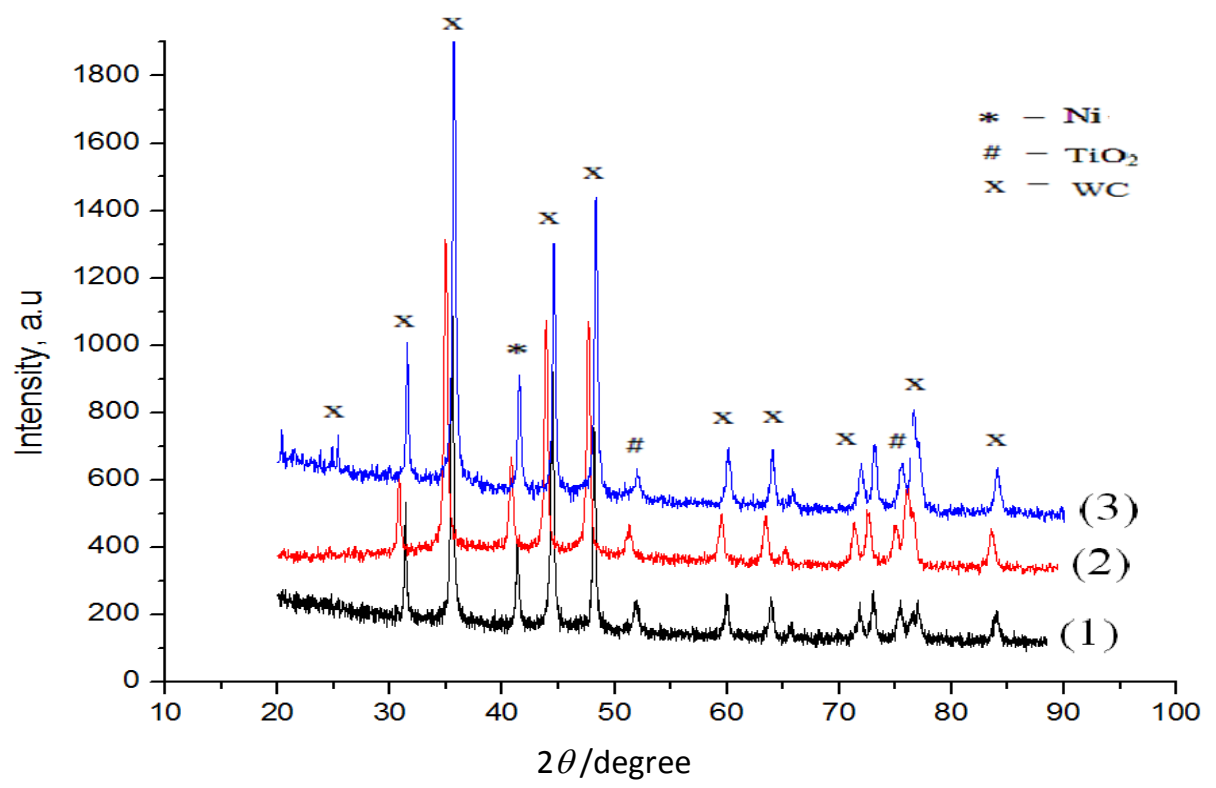

Figure 2. XRD pattern of $\mathrm{Ni}_{-} \mathrm{TiO}_{2}$ composite coating deposited at different conditions:

(1) current $=15 \mathrm{~mA}$ and temperature $=30^{\circ} \mathrm{C}$; (2) current $=15 \mathrm{~mA}$, temperature $=30^{\circ} \mathrm{C}, \mathrm{pH} 4.5$

(3) $0.4 \% \mathrm{TiO}_{2}$, current $=15 \mathrm{~mA}$, temperature $=30^{\circ} \mathrm{C}, \mathrm{pH} 4.5$ 
The figure shows that the composite coatings consist of $\mathrm{Ni}$ phase and $\mathrm{TiO}_{2}$ phase. For $\mathrm{Ni}$, the diffraction peaks at $44.54^{\circ}$. For $\mathrm{TiO}_{2}$, the diffraction peaks at $51.96^{\circ}$ and $75.51^{\circ}$. According to the XRD data, the average grain size of $\mathrm{Ni}$ and $\mathrm{TiO}_{2}$ can be calculated using Eq. (1). The results are shown in Table 2. The XRD results demonstrate the average grain diameters of $\mathrm{Ni}$ and $\mathrm{TiO}_{2}$ in the composite coating prepared by electrocodeposition. At lower current, that is, $15 \mathrm{~mA}$, the average grain sizes of $\mathrm{Ni}$ and $\mathrm{TiO}_{2}$ are 60 and $19.65 \mathrm{~nm}$, respectively, while at $\mathrm{pH} 4.5$ the average grain sizes of the coating are 73.1 and $23.84 \mathrm{~nm}$ respectively. These results are consistent with the AFM results.

Table 2. Average grain size of $\mathrm{Ni}$ and $\mathrm{TiO}_{2}$ composite coatings

\begin{tabular}{ccc}
\hline Type of coatings & $D_{\mathrm{Ni}} / \mathrm{nm}$ & $D_{\mathrm{TiO}_{2}} / \mathrm{nm}$ \\
$(1)$ & 60.0 & 19.65 \\
$(2)$ & 73.1 & 23.84 \\
$(3)$ & 51.3 & 25.70 \\
\hline
\end{tabular}

Mechanical properties of $\mathrm{Ni}$ - $\mathrm{TiO}_{2}$ coatings

Mechanical properties such as microhardness play an important role in tool life enhancement. The inclusion of nano-sized $\mathrm{TiO}_{2}$ particles in the metal matrix deposit is dependent on parameters like $\mathrm{pH}$ concentration, current density, temperature, stirring rate, and so on. The microhardness of the samples was examined by applying a $0.5-\mathrm{kg}$ force load using a Vickers microhardness tester (Mitutoyo). After coating deposition, six indentations were made at different places and the mean of these values was taken. The effect of the applied current, the $\mathrm{pH}$ value of the Watts solution, and the percentage concentration of $\mathrm{TiO}_{2}$ nanoparticles in solution by volume directly affected the microhardness of the composite coatings. The effects of these parameters are discussed below.

\section{Effect of current on microhardness of $\mathrm{Ni}-\mathrm{TiO}_{2}$ coatings}

$\mathrm{Ni}-\mathrm{TiO}_{2}$ composite coating is deposited on the cutting tool bit by varying the applied current from 15 to $45 \mathrm{~mA}$. The effect of the current density applied during the process is studied by measuring the microhardness of the composite coatings. The morphological characterization of as-prepared samples was done using a scanning electron microscope (JEOL JSM 6510 LV) at an accelerating voltage of $20 \mathrm{kV}$ as shown in Figure 3. The change in structure of the composite layer is observed with changes in current density at constant time of deposition. Fine close-grained structures are observed at low current as shown in Figure 1. On examination of all coated layers, some fine cracks are found in the layer deposited at higher current, that is, at $45 \mathrm{~mA}$.
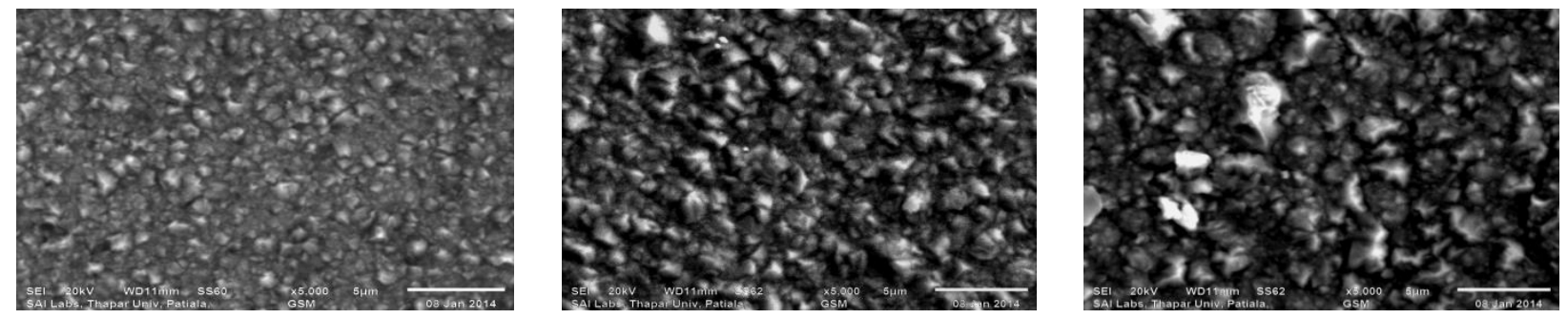

Figure 3. SEM photographs of $\mathrm{Ni} / \mathrm{TiO}_{2}$ composite layers at currents of 15, 30, and $45 \mathrm{~mA}$

The microhardness of $\mathrm{Ni}-\mathrm{TiO}_{2}$ composite coatings is a function of the grain structure developed during the process. The increase in microhardness of $\mathrm{Ni}-\mathrm{TiO}_{2}$ composite coatings can be explained on the basis that $\mathrm{TiO}_{2}$ nanoparticles are uniformly distributed in the Ni matrix. Further it is found 
that growth of the $\mathrm{Ni}$ grains, through its grain refining and dispersive strengthening effects, also affects the microhardness of coatings [13].

As shown in Fig. 3, the SEM results shows that at lower current, that is, at $15 \mathrm{~mA}$, a fine closegrained structure is observed, whereas the course grain structure is observed at current intensities of 30 and $45 \mathrm{~mA}$. The measurements show that the microhardness is influenced by the change in current density as shown in Fig. 4. The measurements were carried out three times for each sample to confirm the reproducibility of the results, and the maximum indentation depth was of the order of $1 \mu \mathrm{m}$.

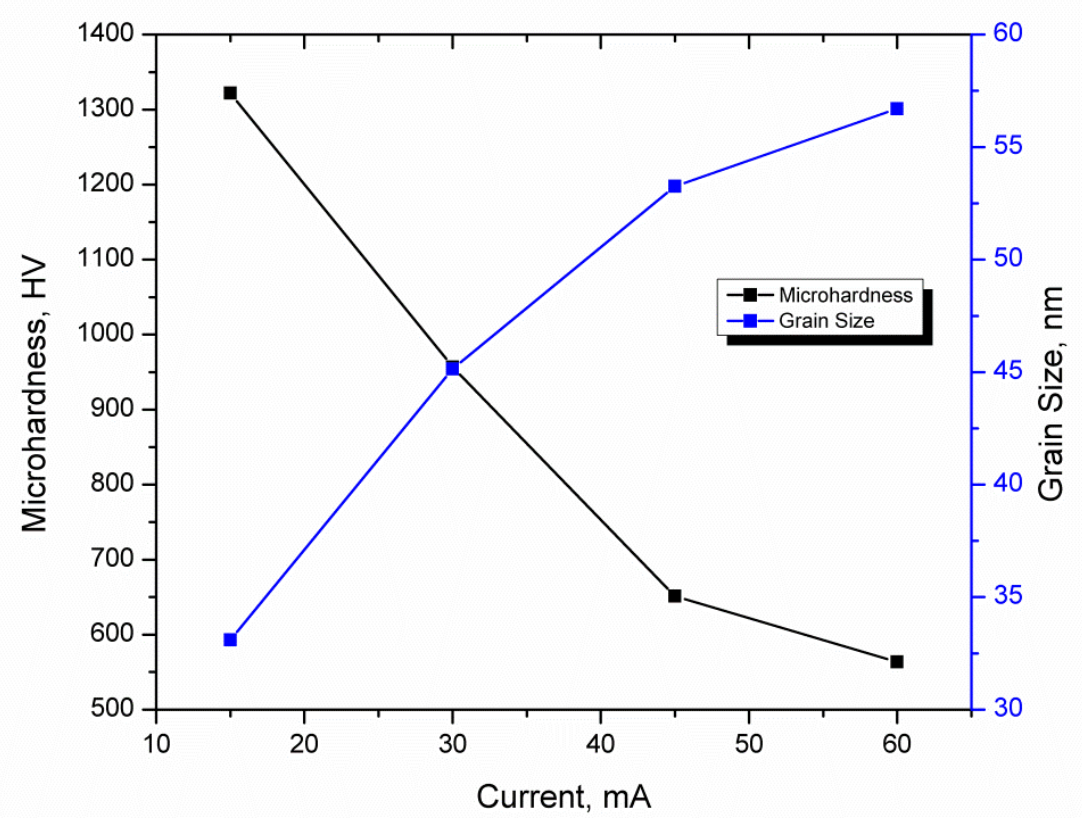

Figure 4. Effect of current on microhardness and grain size of composite layer at $\mathrm{pH} 3.5$ and temperature of $30^{\circ} \mathrm{C}$.

In nanocomposite coatings, it is found that dispersion strengthening is largely due to the uniform distribution of $\mathrm{TiO}_{2}$ nanoparticles in the coatings. Such particles possess higher density and fine size, and close and fine grains are obtained in the composite [14]. Codeposition of fine $\mathrm{TiO}_{2}$ nanoparticles in $\mathrm{Ni}$ matrix restrained the growth of large $\mathrm{Ni}$ grains, resulting in the finegrained structure of the composite layer. Further dispersive strength obtained during the reinforcement phase acts as a barrier that retards the plastic deformation of the $\mathrm{Ni}$ matrix, resulting in high microhardness of the composite coatings [15]. Accordingly, higher microhardness and improved friction and wear properties are found in the hardened matrix.

\section{Effect of $\mathrm{pH}$ value on microhardness of $\mathrm{Ni}-\mathrm{TiO}_{2}$ coatings}

In electrodeposition, the $\mathrm{pH}$ value of the solution is a vital parameter to be controlled to maintain the process optimization. If the $\mathrm{pH}$ of the Watts electrolyte is too high or too low due to chloride ion concentration, more oxygen will evolve and then hydroxyl ions will be discharged in preference to the dissolution of nickel. Under this condition, the nickel anode becomes passive and the efficiency of anode dissolution is almost zero $[16,17]$. The $\mathrm{pH}$ value of the bath influences the hydrogen evolution voltage, the precipitation of basic inclusion, and the decomposition of the complex or hydrate from which the metal is deposited. In a complex bath, the $\mathrm{pH}$ may influence the equilibrium between various processes. When the anode is insoluble, oxygen evolution takes place at the anode:

$$
2 \mathrm{H}_{2} \mathrm{O} \rightarrow \mathrm{O}_{2}+4 \mathrm{H}^{+}+4 \mathrm{e}^{-}
$$


On the other hand, hydrogen evolution at the cathode is accompanied by the production of hydroxide ions:

$$
2 \mathrm{H}_{2} \mathrm{O}+2 \mathrm{e}^{-} \rightarrow 2 \mathrm{OH}^{-}+\mathrm{H}_{2}
$$

If the current efficiency is greater at the anode than at the cathode, the bath becomes more alkaline. If the electrode efficiencies are similar, the $\mathrm{pH}$ of the bath remains unchanged. Hence a change in $\mathrm{pH}$ of a plating bath is a good indication of electrode efficiencies. Since it is not possible to predict all the factors, the best $\mathrm{pH}$ range must be determined empirically for specific coating compositions. In this study, coating has been done at different $\mathrm{pH}$ concentrations of the Watts solution of $3.5,4.5$, and 5.5. The effects of the quality of coatings were investigated using constant conditions of a current density of $15 \mathrm{~mA}$, temperature of $50{ }^{\circ} \mathrm{C}$, deposition time of $1200 \mathrm{~s}$, and stirring rate of $210 \mathrm{rpm}$. Figure 5 shows the microhardness of the composite layer at different $\mathrm{pH}$ values at a current of $15 \mathrm{~mA}$.

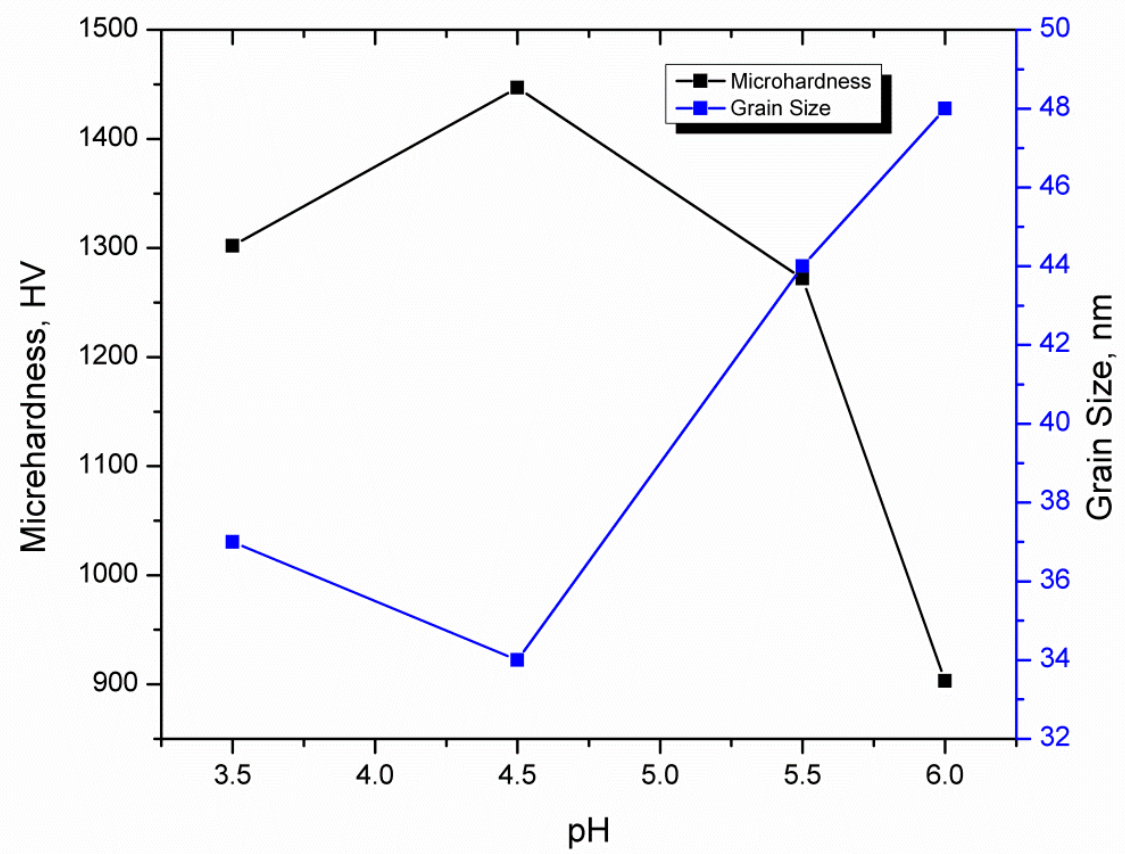

Figure 5. Effect of $\mathrm{pH}$ value on microhardness and grain size of composite layer at a current of $15 \mathrm{~mA}$ and temperature of $30^{\circ} \mathrm{C}$

The microhardness, which is mainly dependent on the grain size, is influenced by the $\mathrm{pH}$ value of the solution. Figure 6 shows the SEM cross-sectional image of $\mathrm{Ni}-\mathrm{TiO}_{2}$ composite coatings produced at $\mathrm{pH}$ concentrations of $3.5,4.5$, and 5.5 .
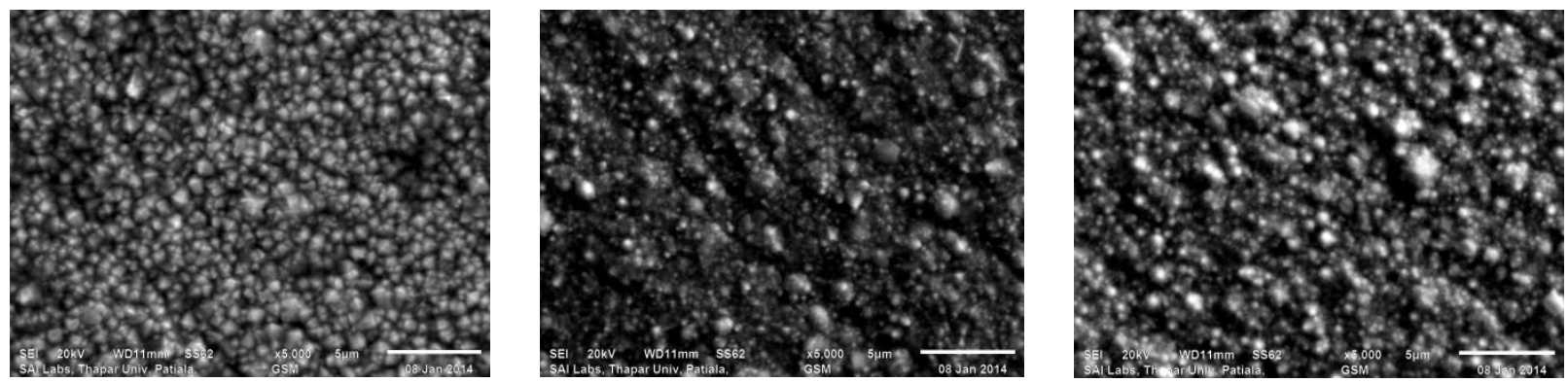

Figure 6. SEM photomicrographs of $\mathrm{Ni} / \mathrm{TiO}_{2}$ composite layer at $\mathrm{pH} 4.5,5.5$, and 3.5, respectively.

The micrographs shows a dark dispersion uniformly distributed all over the coatings and XRD analysis of these dispersions reveals the dark area to be rich in $\mathrm{TiO}_{2}$ particles; however the 
concentration of $\mathrm{TiO}_{2}$ particles in the coating varied with changes in the $\mathrm{pH}$ of the electrolyte. The amount of $\mathrm{TiO}_{2}$ particles is highest at $\mathrm{pH} 4.5$.

\section{Effect of $\mathrm{TiO}_{2}$ particle concentration on the microhardness of composite coatings}

The incorporation of $\mathrm{TiO}_{2}$ nanoparticles in the nickel matrix leads to the formation of finer-grained structures, which further decreases the residual tensile stresses and increases the microhardness and wear and corrosion resistance of the composite coatings [18]. During electrodeposition a coating of a thin layer of one metal is deposited on top of a different metal at different concentrations of $\mathrm{TiO}_{2}$ nanoparticles in the solution in order to modify the surface properties.

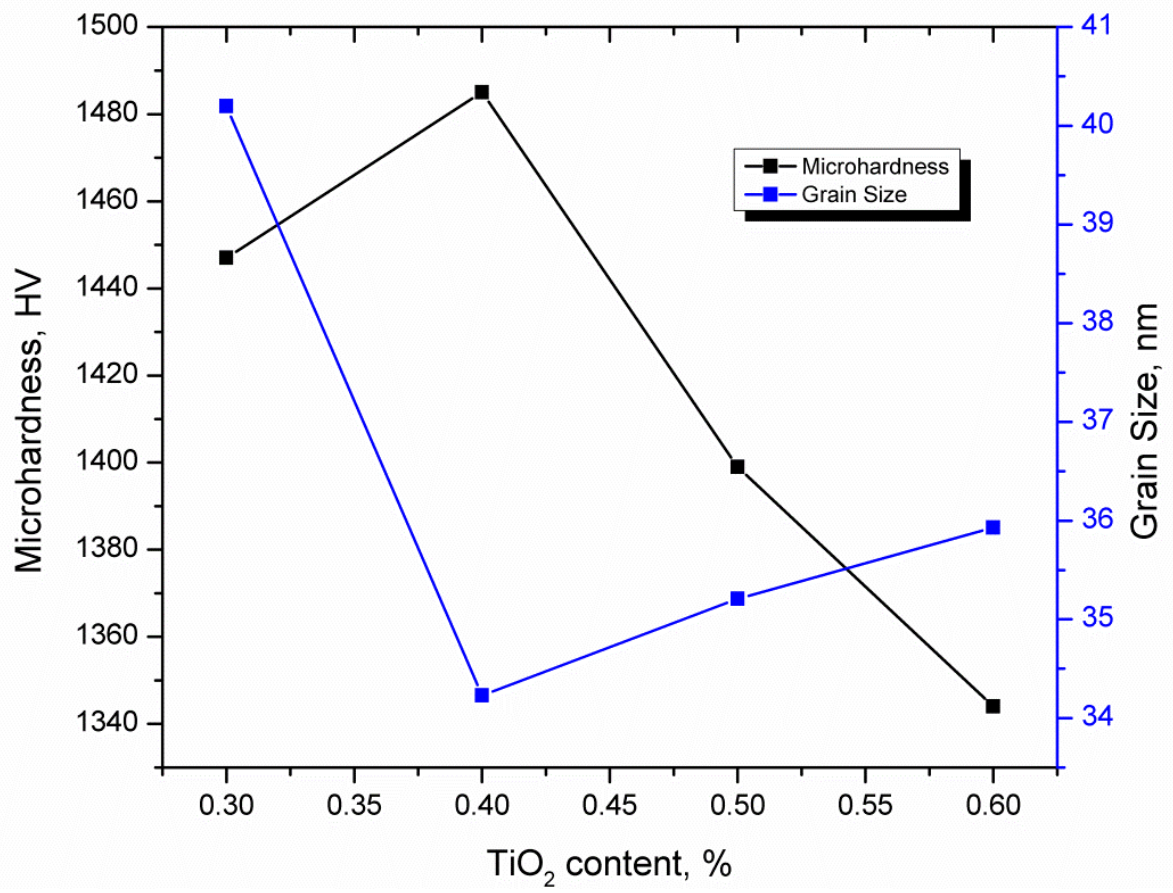

Figure 7. Effect of $\mathrm{TiO}_{2}$ content on microhardness and grain size at current $=15 \mathrm{~mA}, \mathrm{pH}=4.5$, and temperature $=30^{\circ} \mathrm{C}$.

Deposition was carried out by varying the concentration of $\mathrm{Ti}^{-} \mathrm{O}_{2}$ nanoparticles in Watts solution from 0.3 to $6 \mathrm{~g} \mathrm{~L}^{-1}$ at a lower current, that is, $15 \mathrm{~mA}$, and a solution $\mathrm{pH}$ of 4.5 . The microhardness of each composite coating was measured and the maximum microhardness was found at $0.4 \mathrm{~g} \mathrm{~L}^{-1}$ solution. The addition of more solution had a negligible effect on the coating as shown in Fig. 7. When $\mathrm{TiO}_{2}$ nanoparticles were added to the electrolytic bath of Watts solution, the borders of the $\mathrm{Ni}$ grains became more localized, resulting in a reduction in mean grain size compared to pure $\mathrm{Ni}$. The addition of $\mathrm{TiO}_{2}$ nanoparticles to the nickel matrix changed the structure of the composite coatings. According to Scherrer's equation, with increasing content of particles in the coating, the Ni grains decrease in size [13].

\section{Conclusions}

Electrodeposition is a versatile route for depositing composite coatings of $\mathrm{Ni}-\mathrm{TiO}_{2}$ on the surface of cutting tools. Moreover the setup cost for electrodeposition coating is quite low compared to other conventional coating processes like CVD and PVD. In this work, a $\mathrm{Ni}^{-\mathrm{TiO}_{2}}$ nanocomposite coating was deposited on a WC cutting tool by the electrodeposition technique in order to improve the mechanical properties. The effects of the applied current, $\mathrm{pH}$ of the solution, and $\mathrm{TiO}_{2}$ particle concentration were studied. The microstructure and phase structure of the composite 
layer were investigated using atomic force microscopy, scanning electronic microscopy, and X-ray diffraction.

It was found that the surface morphology of $\mathrm{Ni}^{-\mathrm{TiO}_{2}}$ coating was crack free at lower current densities; however some fine cracks appeared at high current densities, which means that $\mathrm{Ni}^{-\mathrm{TiO}_{2}}$ coatings are prone to cracking at higher current density. The microhardness of $\mathrm{Ni}^{-\mathrm{TiO}_{2}}$ coatings decreases due to increases in grain size and decreases in tungsten content. The highest microhardness value is obtained at a lower current, that is, $15 \mathrm{~mA}$. The $\mathrm{pH}$ value of the electrolyte bath influences the hydrogen evolution voltage. The microhardness of the composite layer is influenced by the $\mathrm{pH}$ value of the solution. A higher microhardness value is obtained at $\mathrm{pH} 4.5$ at lower current density. Further addition of $\mathrm{TiO}_{2}$ nanoparticles was carried out and the maximum microhardness of $1484 \mathrm{HV}$ was found at $0.5 \% \mathrm{TiO}_{2}, \mathrm{pH} 4.5$, and a current of $15 \mathrm{~mA}$.

\section{References}

[1] C. S. Lin, C. Y. Lee, C. F. Chang, Surf. Coat. Technol. 200 (2006) 3690-3697.

[2] M. Schlesinger, M. Paunovic, Modern Electroplating, John Wiley \& Sons, Inc., Hoboken, New Jersey, USA, 2010.

[3] J. H. W. Loffler, Surf. Coat. Technol. 68/69 (1994) 729-736.

[4] H.-J.Schröder, G.K.Wolf, Surf. Coat. Technol. 74/75 (1995) 178-186.

[5] H. Kupfer, F. Richter, S. Friedrich, H-J. Spies, Surf. Coat. Technol. 74/75 (1995) 333-339.

[6] S. B. Sant, K. S. Gill, Surf. Coat. Technol. 68/69 (1994) 152-161.

[7] G. Berg, Ch. Friedrich, E. Broszeit, Ch. Berger, Surf. Coat. Technol. 86/87 (1996) 184-191.

[8] T. Hurkmans, D. B. Lewis, J.S. Brooks, Surf. Coat. Technol. 86/87 (1996) 192-201.

[9] O. Knotek, W. Bosch, M. Atzor, D. Hoffmann, J. Goebel, High Temp.-High Press 18 (1986) 435-443.

[10] S. Spanou, E. A. Pavlatou, J. Appl. Electrochem. 40 (2010) 1325-1336.

[11] W. Chen, Y. He, W. Gaoa, J. Electrochem. Soc. 157/8 (2010) 122-128.

[12] G. A. Di Bari, Electrodeposition of Nickel, in Modern Electroplating, John Wiley \& Sons, Inc., Hoboken, NJ, USA, 2010

[13] A. Sadeghi, R. Khosroshahi, Z. Sadeghian, J. Surf. Invest.-X-ray+ 5(1) (2011) 186-192.

[14] L. Chen, L. Wang, Z. Zeng, J. Zhang, Mater. Sci. Eng., A 434 (2006) 319-328.

[15] M. Momenzadeh, S. Sanjabi, Mater. Corros. 63(7) (2012) 614-619.

[16] J. Tientong, C. R. Thurber, N. D'Souza, A. Mohamed, T. D. Golden, Int. J. Electrochem (2013) Article ID 85386, 1-8.

[17] Z. Abdel Hamid, S.M. El-Sheikh, J. Metall. Eng. 2 (2013) 71-79.

[18] S. Spanou, E. A. Pavlatou, N. Spyrellis, Proceedings of the $7^{\text {th }}$ International Conference Coatings in Manufacturing Engineering, Chalkidiki, Greece, 2008, p. 57-71.

(C) 2015 by the authors; licensee IAPC, Zagreb, Croatia. This article is an open-access article distributed under the terms and conditions of the Creative Commons Attribution license (http://creativecommons.org/licenses/by/4.0/) (cc) EY 